Vavilow propounded as the law of homologous variation. He eagerly joined issue in the controversy about Cuénot's yellow mice, which was not cleared up until Little introduced the idea of lethal factors. Likewise he was in the thick of the dispute about the Himalayan rabbit, a perplexing case before the days of multiple allelomorphs. Throughout his life he stoutly defended against all deviationists the presence and absence theory in its original form.

Hagedoorn's real bent lay in the field of applied genetics. On his return from America, he joined the firm of Vilmorin, the leading seedsmen in France. A few years later, in 1914, he was sent to Java by the Dutch Government to organize the fight against rats in that island. He returned to California in 1916, and then after two years in Berlin with Erwin Baur he settled down in Holland at Soesterberg, where he quickly established himself as a consulting geneticist, both for plant and animal breeders. He also taught in the University of Leyden, and became secretary of the Dutch Genetical Society. He was thus most favourably placed between science and practice, and, with a foot in both camps, he became a familiar figure wherever geneticists or practical breeders were gathered together.

$\mathrm{He}$ is best known in Great Britain for his textbook on animal breeding, the tenth edition of which is due to appear in 1954. In 1950 he published a companion text-book on plant breeding, and in 1953, in collaboration with Geoffrey Sykes, he published a book on poultry breeding. His writing is attractive and persuasive, though coloured with an enthusiasm which sometimes got the better of his good judgment. Since 1945 he has been a frequent visitor to Britain, where he lectured to gatherings of live-stock breeders, both of farm animals and of the fancy. His very great knowledge of the practical problems involved, and his very real understanding of the outlook of the practical man, enabled him to talk to breeders in a language they understood. Few geneticists have been as successful as Hagedoorn in conveying to the practical man the importance of Mendelism to the art of breeding.

Michael Pease

\section{Mr. J. D. Griffith Davies, O.B.E.}

A WIDE circle of scientists throughout the world will have learned with regret of the death on December 18 of John David Griffith Davies, who was assistant secretary of the Royal Society during $1937-46$.

He was born on January 19, 1899, and went from Monmouth School to Jesus College, Oxford, after a period of war service during 1916-19. He graduated in the Honours School of Modern History in 1923 and after a few years teaching in school he joined the City of Leeds Education Department in 1926; he was appoirited assistant secretary of the Royal Society in 1937. It was largely during the period in Leeds that he wrote about a dozen books on historical subjects.

Griffith Davies served the Royal .Society under three presidents, Sir William Bragg, Sir Henry Dale and Sir Robert Robinson. With characteristic energy he applied his considerable talents to problems which faced the Society during the period dominated by the threat of war and war itself. He took a leading part in the construction of the Central Scientific Register, which did much to help in the mobilization of British scientific effort. He had to supervise the transfer of the Society's treasures and library to safe quarters. After the War, when the Society again resumed its full scientific activity in peace-time conditions, Griffith Davies was intimately concerned with the organization of the Newton Celebrations and the Royal Society Empire Scientific Conferencetwo events which were outstanding in the revival of Commonwealth and international scientific relations. In 1947 he was made O.B.E.

On his retirement from the Society's service, he endowed the Wilkins Lecture in the history of science, and although his main interests thereafter were centred on his farm in Gloucestershire, he maintained close contact with the Society's affairs.

$\mathrm{He}$ will be remembered with affection by those who came in contact with him in his wide range of interests.

\title{
NEWS and VIEWS
}

\section{New Year Honours List}

THE list of New Year Honours includes the names of the following men of science and others associated with scientific work :

K.B.E. : Commander Seton S. C. Mitchell, controller of guided weapons and electronics, Ministry of Supply.

Knights : Arthur L. Binns, chief education officer for Lancashire; Prof. Edward C. Dodds, Courtauld professor of biochemistry, University of London; Prof. James Gray, professor of zoology, University of Cambridge, member of the Development Commission; Dr. Edward T. Paris, chief scientific adviser, Home Office; Dr. William G. Radley, engineer-in-chief, Post Office; Dr. Douglas Veale, registrar, University of Oxford.

C.B. : A. T. Barnard, chief superintendent, Royal Ordnance Factories, Woolwich; Dr. J. M. Stagg, principal deputy director, Meteorological Office, Air Ministry.

C.M.G. : R. E. Brook, deputy chairman, Colonial Development Corporation ; Ian Clunies-Ross, chairman, Scientific and Industrial Research Organization,
Commonwealth of Australia; G. S. Dunnett, secretary, Commonwealth Economic Committee; G. Michael Graham, director of fishery research, Ministry of Agriculture and Fisheries ; Colonel H. W. Mulligan, director, West African Institute for Trypanosomiasis Research; A. E. Trotman, member for Agriculture and Natural Resources, Tanganyika.

C.B.E. : Dr. D. A. Allan, director, Royal Scottish Museum; W. Allan, director of agriculture, Mauritius ; Prof. G. D. Allen, professor of statistics, University of London ; H. Cronly, director of veterinary services and animal industry, Uganda; St. J. de H. Elstub, director of the Metal Division, Imperial Chemical Industries, Ltd. ; Prof. T. Ferguson, professor of public health, University of Glasgow; Dr. J. B. Firth, director, North Western Forensic Science Laboratory, Home Office; R. D. Gwyther, senior partner, Coode and Partners, consulting civil engineers, London ; Miss Kathleen M. Kenyon, lecturer in Palestinian archæology, University of London Institute of Archæology; G. J. S. Little, assistant engineer-in-chief, General Post Office; Dr. K. Mellanby, lately principal, University College, Ibadan, Nigeria; J. H. Nicholson, principal, University 